\title{
The severity of congenital syphilis in an unscreened newborn in the delivery room
}

\author{
A gravidade da sífilis congênita em recém-nascido não triado na sala de parto \\ La gravedad de la sífilis congénita en un recién nacido no cribado en la sala de partos
}

Received: 01/12/2022 | Reviewed: 01/13/2022 | Accept: 01/13/2022 | Published: 01/15/2022

Iêda Maria Rodrigues Vilela Demirdjian

ORCID: https://orcid.org/0000-0002-5281-9865

Hospital Universitário Maria Aparecida Pedrossian, Brasil

E-mail: ieda_vilela@hotmail.com

Nádia Margarida Rodrigues Chaves Vilela Fante

ORCID: https://orcid.org/0000-0001-8806-1120

Universidade Federal de Mato Grosso do Sul, Brasil

E-mail: nadia_vilela@hotmail.com

\begin{abstract}
Syphilis, despite all the use of Health Policies to minimize its occurrence, for various reasons, continues to affect pregnant women, newborns, and children. The objective of this work is to report a case of congenital syphilis with late diagnosis in a teaching hospital. It is a disease of easy diagnosis and treatment, with a historical reduction after the discovery of penicillin in the 40's. However, in the 21 st century this pathology has returned to a significant growth, with this, the lack of attention is highlighted. pre- and post-natal care for the screening and diagnosis of the disease. In order to treat the child in advance, many times, even before the symptoms appear. This work seeks to report a case of late diagnosed congenital syphilis, showing the damage caused by the disease and emphasizing the importance of screening, diagnosis, and treatment.
\end{abstract}

Keywords: Syphilis; Congenital syphilis; Infectious disease transmission, vertical.

\section{Resumo}

A sífilis, apesar de todo o emprego das Políticas de Saúde em minimizar sua ocorrência, por diversas razões, continua acometendo gestantes, recém-nascidos e crianças. O objetivo deste trabalho visa relatar um caso de sífilis congênita com diagnóstico tardio em um hospital de ensino. Trata-se de uma doença de fácil diagnostico e tratamento, tendo uma redução histórica após a descoberta da penicilina na década de 40. Porém, no século 21 tal patologia voltou a ter um crescimento significativo, com isso, destaca-se a falta de atenção no pré e pós-natal para o rastreio e diagnóstico da doença. Visando assim, tratar a criança previamente, muitas vezes, antes mesmos dos sintomas aparecerem. Este trabalho busca relatar um caso de sífilis congênita tardiamente diagnosticada, mostrando os danos causados pela doença e ressaltando a importância do rastreio, diagnóstico e tratamento da mesma.

Palavras-chave: Sífilis; Sífilis congênita; Transmissão vertical de doenças infecciosas.

\section{Resumen}

La sífilis, a pesar de todo el uso de Políticas de Salud para minimizar su ocurrencia, por diversas razones, continúa afectando a mujeres embarazadas, recién nacidos y niños. El objetivo de este trabajo es reportar un caso de sífilis congénita con diagnóstico tardío en un hospital escuela. Es una enfermedad de fácil diagnóstico y tratamiento, con un descenso histórico tras el descubrimiento de la penicilina en la década del 40. Sin embargo, en el siglo XXI esta patología ha vuelto a tener un crecimiento importante, con ello se pone de relieve la falta de atención. y atención posnatal para el tamizaje y diagnóstico de la enfermedad. Para tratar al niño con anticipación, muchas veces, incluso antes de que aparezcan los síntomas. Este trabajo busca reportar un caso de sífilis congénita de diagnóstico tardío, mostrando los daños causados por la enfermedad y enfatizando la importancia del tamizaje, diagnóstico y tratamiento. Palabras clave: Sífilis; Sífilis congénita; Transmission verticale de maladie infectieuse.

\section{Introduction}

Syphilis is a curable, sexually transmitted infection caused by Treponema pallidum, which is a bacterium in the spirochete group. Its incidence declined after the discovery of penicillin in 1940, but it resurfaced dramatically in the late 1980s, related to HIV co-infection. (Zugaib \& Francisco, 2016). Congenital syphilis is a disease that severely affects newborns in a multisystemic way, it can even be fatal. It occurs by the hematogenous dissemination of Treponema pallidum, from the infected pregnant woman, untreated or inadequately treated, to her fetus, through the placenta. Although it can be avoided with 
adequate prenatal care, congenital syphilis still affects many newborns in Brazil (Gameiro, et al., 2017).

Considered a serious public health problem at a global level, congenital syphilis has been available for low-cost diagnostic methods and effective treatment since the 1950s. The disease presents a worse scenario than the vertical transmission of the human immunodeficiency virus (HIV) and is a determining factor in raising maternal and perinatal morbidity and mortality indicators (Cavalcante et al., 2017). In 2011, the World Health Organization (WHO) estimated that 2 million cases of syphilis occur in pregnant women annually. About $25 \%$ of untreated or inadequately treated cases would result in miscarriage or stillbirth (Brasil, 2015).

A few years ago, the supply of penicillin in Brazil and in several other countries was threatened, since the beginning of the 1990s, Brazil became an exclusive importer of raw materials for the fine chemical industry. Thus, in order to produce penicillin, the country depends on the importation of Active Pharmaceutical Ingredients, which are sometimes lacking or with quality problems. This is what happened in 2018, when the Fundação para o Remédio Popular managed to deliver only half of the order for ampoules, because of the difficulty in producing the drug properly due to the lack of quality in the IFA (Alves et al., 2020). The shortage of penicillin may have favored the increase in the incidence of the disease, but the lack of medication has already been solved. Thus, other factors, including social ones, are involved in the growth in the number of cases and in the perpetuation of this chronic systemic disease capable of causing serious sequelae, but whose diagnosis is simple and treatment is cheap and effective (Vidal \& Mascarenhas, 2020).

The fundamental premise of effective syphilis control is serological screening and adequate treatment of pregnant women and sexual partners, since the quality of prenatal and childbirth care is an important determinant in reducing vertical transmission (Brasil, 2015). Penicillin is the drug of first choice in the treatment of syphilis and the only one indicated for pregnant women: it is $98 \%$ effective in preventing congenital syphilis, acting in all stages of the disease. There is no report of resistance of Treponema pallidum to penicillin. Nevertheless, the high incidence of syphilis in pregnant women and congenital syphilis remains a challenge for health services (Cavalcante et al., 2017).

The present study aims to report a case of congenital syphilis in a child who, despite being born in a qualified hospital, did not pass the screening tests; with this, we intend to emphasize the importance of neonatal screening and monitoring of the child to reduce the high rates of an old, curable, and neglected pathology by many.

\section{Methodology}

This is a case study of a patient treated at the Maria Aparecida Pedrossian University Hospital, and a case study is a description and analysis, as detailed as possible, of a case that presents some particularity that makes it special (Pereira, et al., 2018). The project carried out was submitted to the Ethics and Research Committee and approved under number 5,167,197. To obtain data, the patient's medical records and the institution's database were reviewed. The study was carried out at the Maria Aparecida Pedrossian University Hospital located in Campo Grande - MS (refers to a public institution, with tertiary care). Also, the Free and Informed Consent Term (FICT) of the person responsible for the patient participating in the research was collected. This term was collected in person, taking into account that the patient is in outpatient follow-up of the pathology in question.

The sample used was hospital-based, selected from the patient's medical records. Data were typed into the Microsoft Office Word program without any kind of patient identifier.

\section{Case}

Male patient, born on 02/08/2021. Mother performed complete prenatal care (with 8 documented consultations), 
performed maternal screening tests in the first and third trimesters of pregnancy, and was negative for any sexually transmitted diseases in both tests. At hospital admission for delivery, the mother was screened for syphilis, HIV, and hepatitis B, with negative results for both pathologies. The newborn was born in good general condition, was not screened for syphilis, and was discharged at 48 hours of life (Figure 1).

Figure 1: Patient with 1 day of life, presenting lesions in the upper limbs.

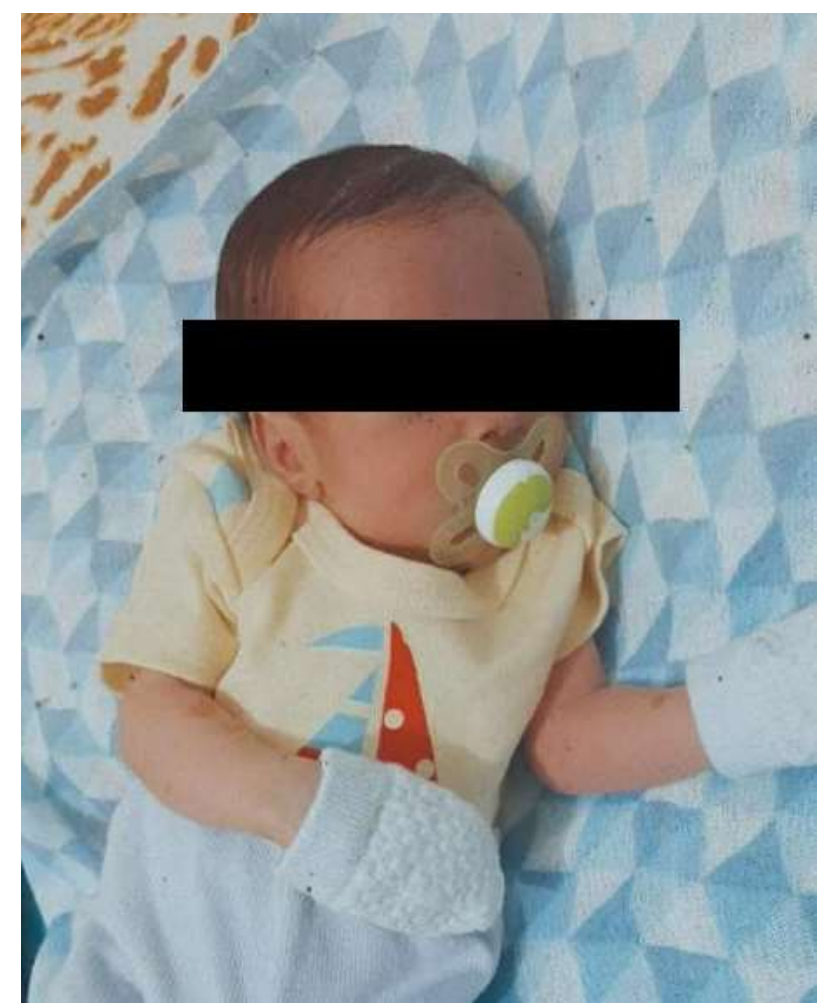

Source: Authors.

With 15 days of life, the mother sought the UBSF for a childcare consultation, with a complaint of a reduction in her child's breastfeeding, the doctor's examination showed weight loss (she could not say how much) and prescribed supplementation with infant formula. When the newborn was 22 days old, the mother returned to the UBSF reporting that the child had fever, reduced feedings and multiple lesions on the body, antipyretics and topical medications were prescribed for the lesions. However, at 30 days of age, her son developed fever, vomiting, diarrhea, increased lesions and stopped breastfeeding, so the mother sought the hospital in the city of origin, where her son was referred to Campo Grande - MS for treatment. the Maria Aparecida Pedrossian University Hospital (HUMAP). He was admitted to this hospital on 03/12/2021 with 1 month and 5 days of life, without comorbidities, referred as an outpatient with fever, severe dehydration, and numerous scaly lesions throughout the epidermis, predominantly in the mouth, genitals and anus (Figure 2). 
Figure 2: Injuries presented at hospital admission.

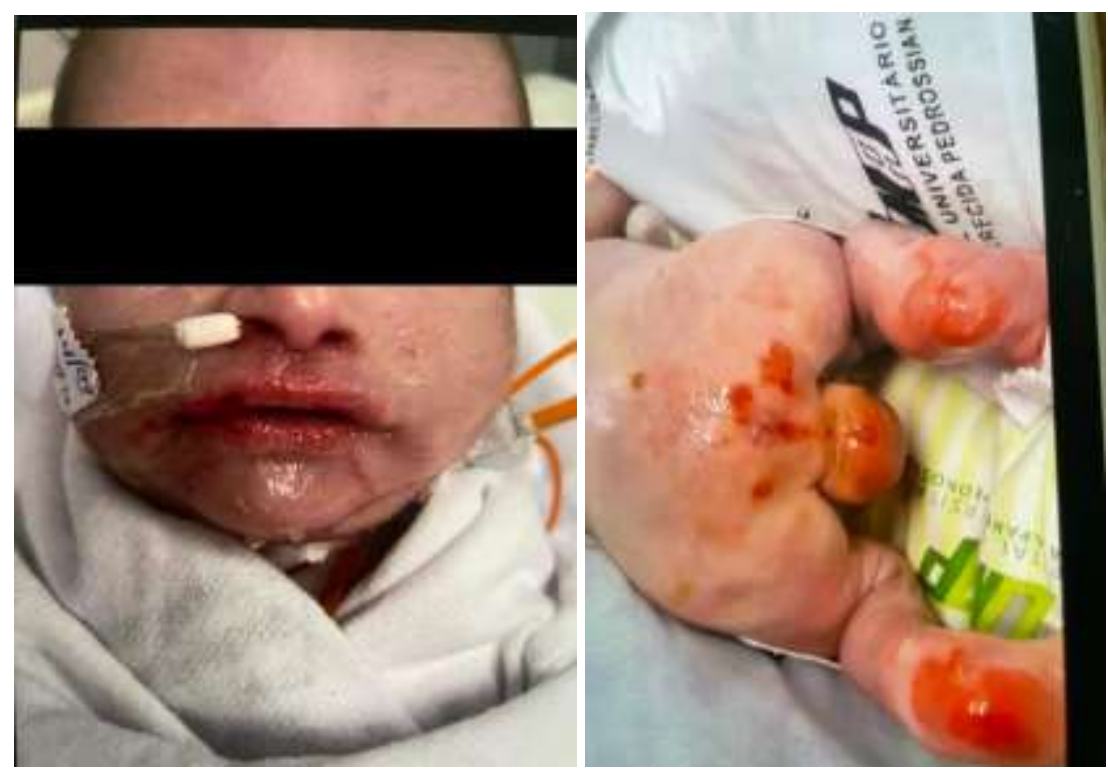

Source: Authors.

After admission to the hospital's emergency medical care, the patient was screened with laboratory tests showing VDRL of 1/1024 (baby) and mother VDRL > 1/1128 and started Crystalline Penicillin, with this, an ICU vacancy was immediately requested due to the severity of the case, patient was transferred to the Intensive Care Center on the third day of hospitalization and remained 27 days receiving treatment, there, volume expansion, hydration with crystalloids, blood transfusion due to acute anemia, plasma transfusion and antibiotic therapy were performed due to sepsis (Figure 3).

Figure 3: Patient evolution during ICU care.

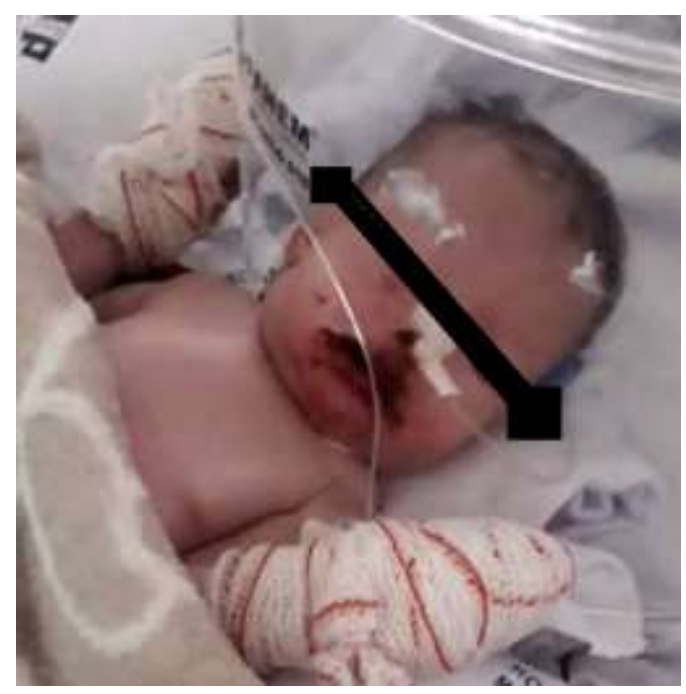

Source: Authors.

After the diagnosis of Syphilis, the patient used Crystalline Penicillin (200,000 IU/Kg/Day - 4/4 hours) for 14 days. On 04/11/2021, the patient was transferred to the ward, where he received care until 04/18/2021, being discharged with followup with the infectology team of this hospital. Patient is in good general condition, with remission of lesions and VDRL with low titer (1/4) (Figure 4). 
Figure 4: Patient currently.

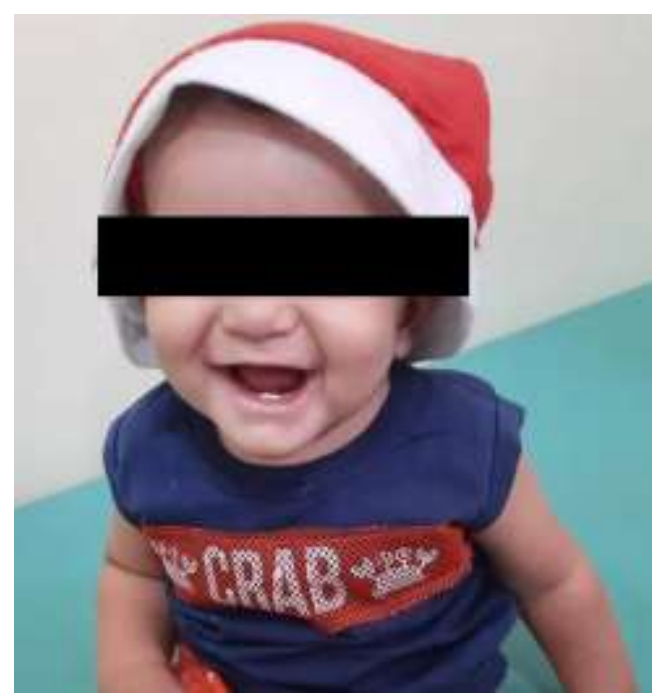

Source: Authors.

\section{Discussion}

More recently, an increase in the incidence of both syphilis and syphilis during pregnancy and congenital was observed in Brazil, indicating a reemergence of the infection in the country. When comparing the incidence of congenital syphilis in Brazil, which ranges from 3.12 to 3.51 cases per thousand live births, with Canada, which between 2010 and 2015 ranged from 0.26 to 1.59 cases for for every 100,000 live births, the dimension and severity of the problem of congenital syphilis in the country can be noted (Cavalcanti, et al., 2019). In the United States, the rate of congenital syphilis has increased since 2012, steadily year on year. In 2018, there were a total of 1306 reported cases, including 78 syphilitic stillbirths and 16 infant deaths. This represents the highest reported rate since 1991. The 2018 case rate (33 cases per 100,000 live births) represents a 40\% increase from 2017 and an almost 400\% increase from 2012 (Dobson, 2021). In Brazil, the increase was significant both in the incidence rate of congenital syphilis and in the rates of detection of syphilis in pregnant women per thousand live births between 2010 and 2017, from 2.4 to 8.6 and from 3.5 to 17.2 cases per thousand live births, respectively (Figueiredo, et al., 2020).

As for the pathophysiology, at the beginning of congenital syphilis, T. pallidum is released directly into the fetal circulation, resulting in spirocheteemia with generalized dissemination to almost all organs. Clinical manifestations result from the inflammatory response. Bones, liver, pancreas, intestine, kidney, and spleen are the most frequently and severely involved. The severity of manifestations is variable and can range from isolated laboratory or radiographic abnormalities to fulminant involvement of multiple organ systems. Overt infection can manifest in the fetus, newborn, or later in childhood (if the baby is untreated) (Dobson, 2021).

When a woman acquires syphilis during pregnancy, there may be asymptomatic or symptomatic infection in newborns. More than 50\% of infected children are asymptomatic at birth, with the first symptoms usually appearing within the first 3 months of life. Therefore, serological screening of the mother in the maternity ward is very important (Brasil, 2019).

Congenital syphilis has two stages: early, diagnosed up to two years of age, and late, after this period. The clinical syndrome of early congenital syphilis appears up to the 2nd year of life and must be diagnosed through a careful epidemiological assessment of the maternal situation and clinical, laboratory and imaging studies in the child. However, the diagnosis in children represents a complex process, in addition to the fact that more than half of all children are asymptomatic at birth and, in those with clinical expression, the signs may be discrete or not very specific, there is no complementary 
evaluation to accurately determine the diagnosis of the infection in the child. From this perspective, it is emphasized that the association of epidemiological, clinical and laboratory criteria should be the basis for the diagnosis (Dobson, 2021).

In addition to prematurity and low birth weight, the main features of this syndrome are, excluding other causes: hepatomegaly with or without splenomegaly, skin lesions (such as palmoplantar pemphigus, flat condyloma), periostitis or osteitis or osteochondritis (with characteristic changes in the radiological study), pseudoparalysis of the limbs, respiratory distress with or without pneumonia, serosanguineous rhinitis, jaundice, anemia, and generalized lymphadenopathy (mainly epitrochlear). Other clinical features include: petechiae, purpura, perioral cleft, nephrotic syndrome, dropsy, edema, seizure, and meningitis. Among the laboratory alterations are: anemia, thrombocytopenia, leukocytosis (leukemoid reaction, lymphocytosis and monocytosis may occur) or leukopenia (Brasil, 2019).

The first choice for the treatment of syphilis is benzylpenicillin, administered intramuscularly in adults, adolescents, and pregnant women. It is a highly effective drug, of high quality, low cost, low toxicity, rare microbial resistance, single dose and without contraindication for use in pregnant women (WHO, 2016). It is, therefore, the only drug recommended for the treatment of syphilis during pregnancy (Rac et al., 2020).

The treatment of congenital syphilis in the neonatal period is performed with benzylpenicillin (potassium/crystalline, procaine or benzathine), depending on maternal treatment during pregnancy or on the titration of a non-treponemic test of the newborn compared to the mother and on clinical and laboratory tests. of child. Cases diagnosed with congenital syphilis after 1 month of age (post-neonatal period) and those with acquired syphilis should be treated with potassium/crystalline benzylpenicillin. The full ten-day regimen with potassium benzylpenicillin/crystalline or procaine should be administered even in situations where the child has received ampicillin for other causes (Domingues, et al., 2021).

\section{Final Considerations}

Syphilis is a known pathology, treatable and still very present in everyday life, in the case in question the patient was not screened due to the history of negative tests presented by the mother. Considering that the mother's prenatal care is complete, the diagnosis in the neonate becomes difficult. Showing the importance of performing the screening test in newborns regardless of the mother's prenatal care, since, due to the immunological window of the disease, the patient can present a false negative.

\section{References}

Alves R. L., Ribeiro Á. \& Minarini L. (2020). O impacto do desabastecimento de penicilina no tratamento da sífilis: crise na relação entre uma doença antiga e um tratamento antigo, porém eficaz. Instituto de Ciências Ambientais, Químicas e Farmacêuticas, UNIFESP. 1, 1-4.

Brasil - Ministério da Saúde. (2015). Secretaria de Vigilância em Saúde. Departamento de DST, Aids e Hepatites Virais. Protocolo clínico e diretrizes terapêuticas para prevenção da transmissão vertical de HIV, sífilis e hepatites virais. Ministério da Saúde. 120 p.

Brasil. (2019). Diretrizes para o controle da Sífilis Congênita. Ministério da Saúde.

Cavalcante P. A. M., Pereira R. B. L. \& Castro J. G. D. (2017). Sífilis gestacional e congênita em Palmas, Tocantins, 2007-2014. Epidemiol. Serv. Saúde. 26 (2).

Cavalcanti G. M., Araújo L. M. C, Fernandes C. L. S. \& Deininger L. S. C. (2019). Transmissão vertical da sífilis na atenção primária: revisão integrativa. Rev. Ciênc. Saúde Nova Esperança. João Pessoa-PB. 17(3), 1-12.

Dobson S. (2021). Congenital syphilis: Clinical features and diagnosis. UpToDate. 1, 1-8.

Domingues C. S. B., Duarte G., Passos M. R. L., Sztajnbok D. C. N. \& Menezes M. L. B. (2021). Brazilian Protocol for Sexually Transmitted Infections 2020: Congenital Syphilis and Child exposed to Syphilis. Journal of the Brazilian Society of Tropical Medicine. 54. 1-10.

Figueiredo D. C. M. M., Figueiredo A. M., Souza T. K. B., Tavares G. \& Vianna R. P. T. (2020). Relação entre oferta de diagnóstico e tratamento da sífilis na atenção básica sobre a incidência de sífilis gestacional e congênita. Cadernos de Saúde Pública. 36(3). 
Research, Society and Development, v. 11, n. 1, e55411125679, 2022

(CC BY 4.0) | ISSN 2525-3409 | DOI: http://dx.doi.org/10.33448/rsd-v11i1.25679

Gameiro V. S., Labronici P. J., Rosa I. M. A. \& Silva J. A. S. (2017). Congenital syphilis with bone lesion: case report. Revista Brasileira de Ortopedia (English Edition). 52(6)

Pereira, A. S., Shitsuka, D. M., Parreira, F. J., \& Shitsuka, R. (2018). Metodologia da pesquisa científica. UFSM. 1-117.

Rac M., Stafford, I., \& Eppes, C. (2020) Congenital syphilis: A contemporary update on ancient disease. Obstetrics \& Gynaecology. 40, $1703-1714$.

Vidal I. R. \& Mascarenhas F. A. N. (2020). Symphilis in pregnancy and congenital syphilis: case report and literature review on its possible causes and strategies of confront in Brazil. Brazilian Journal of Development. 6(10). 1-14.

Zugaib, M. \& Francisco, R. P. V. (2016) Zugaib Obstetrícia. Editora associada Rossana Pulcineli Vieira Francisco, (3a ed.). 